\title{
NEPHROTIC SYNDROME ASSOCIATED WITH TOXOPLASMOSIS. REPORT OF SEVEN CASES
}

\author{
Julio TOPOROVSKI(1), Simone ROMAno(1), Suzana HARTMANN(1), Wanda BENINI(1) \& Pedro Paulo CHIEFFi(2,3)
}

\begin{abstract}
SUMMARY
The concomitance of nephrotic syndrome and acute infection by Toxoplasma gondii is a rare occurrence in humans. In this paper seven cases of children, ranging from 11 months to 7 year-old, with concomitant nephrotic syndrome and asymptomatic acute T. gondii infection are reported. In one of those patients only the administration of anti-Toxoplasma therapy was enough to control the clinical and laboratory manifestations of the disease. In the other patients it was necessary to introduce corticosteroids or other immunosuppressant drugs. Three patients had complete clinical and laboratory improvement and the remaining showed only a partial response.
\end{abstract}

KEYWORDS: Toxoplasma gondii; Nephrotic syndrome; Children.

\section{INTRODUCTION}

Nephrotic syndrome (NS) is mainly characterized by significant proteinuria, defined in children by values larger than either $40 \mathrm{mg} /$ $\mathrm{m}^{2} / \mathrm{h}$ or $50 \mathrm{mg} / \mathrm{kg} /$ day and serum albumin equal or less than $2.5 \mathrm{~g} \%$. The whole picture includes edema, hypercholesterolemia, and urinary excretion of lipids. In childhood NS is primary or idiopathic in $80-90 \%$ of cases; however, NS may be secondary when due to systemic diseases like diabetes or cancer, immune or infectious disorders, besides drug use. Among the infectious causes, in this paper, the association with toxoplasmosis will be highlighted.

Toxoplasma gondii, protozoan agent of toxoplasmosis, belongs to the phylum Apicomplexa and family Sarcocystidae. Although capable of infecting many vertebrate species, both wild and domestic cats are its definitive hosts, also known as complete hosts, because they allow the parasite's full development. Other susceptible hosts, including humans, are considered incomplete hosts, in which the Toxoplasma's life cycle develops only partially.

Infection with $T$. gondii can assume serious aspects when it occurs either in the congenital form or in immunosuppressed patients ${ }^{10}$. In immunocompetent individuals, when transmission occurs after birth, toxoplasmosis commonly has asymptomatic or oligosymptomatic courses. Several forms of presentation are known, with development of variable clinical manifestations; however, renal involvement with glomerulonephritis or nephritic syndrome is a rare event in patients infected with $T$. gondii ${ }^{2,4,7,9,12,13,14,21}$.

Due to the high frequency of toxoplasmic infection it is mandatory in our department to perform anti-Toxoplasma antibody tests in all children with nephrotic syndrome. The aim of this study is to report the clinical, laboratorial, therapeutic, and evolutive aspects of children who had concomitant nephrotic syndrome and $T$. gondii infection.

\section{CLINICAL MATERIAL}

A survey of medical records of outpatients who were diagnosed with nephrotic syndrome and, concomitantly, positivity for IgM antibodies to Toxoplasma, in the Pediatric Nephrology of Santa Casa de Misericórdia de São Paulo was conducted. In the period from 1999 to 2010 seven cases had been found; four were males and three females.

The initial clinical picture was the presence of edema and proteinuria. None of the patients showed specific symptoms for toxoplasmosis, such as fever or lymphadenopathy. The detection of IgM and IgG antiToxoplasma antibodies was performed by enzyme linked immunosorbent assay (ELISA). In six cases renal biopsies had been performed.

Almost all patients were submitted to the following biochemical tests: total cholesterol, serum urea and creatinine, and protein in urine of 24 hours. In only one patient, due to lack of sphincter control, proteinuria was assessed by the protein and creatinine ratio in a unique urine sample. Results of laboratory tests are shown in the Table 1.

All patients received initially anti-toxoplasmosis treatment: sulfadiazine (100 mg/kg/day), pyrimethamine ( $1 \mathrm{mg} / \mathrm{kg} / \mathrm{day})$ and folinic acid (10 mg/day), during at least one month, except those referred by other services, in which steroids had already been administered, receiving anti-Toxoplasma therapy associated to steroids.

(1) Pediatric Department, Medical School of Santa Casa, São Paulo, SP, Brazil.

(2) Pathology Department, Medical School of Santa Casa, São Paulo, SP, Brazil.

(3) Tropical Medicine Institute of São Paulo, São Paulo, SP, Brazil (LIM 06).

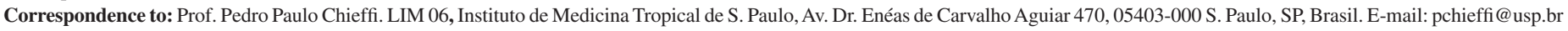


TOPOROVSKI, J.; ROMANO, S.; HARTMANN, S.; BENINI, W. \& CHIEFFI, P.P. - Nephrotic syndrome associated with toxoplasmosis. Report of seven cases. Rev. Inst. Med. Trop. Sao Paulo, 54(2): 61-4, 2012.

Table 1

Clinical, laboratorial and evolutive aspects of seven patients with concomitant nephrotic syndrome and asymptomatic Toxoplasma gondii infection

\begin{tabular}{|c|c|c|c|c|c|c|c|}
\hline Patient & 1 & 2 & 3 & 4 & 5 & 6 & 7 \\
\hline Sex $^{a} /$Age $^{b}$ & $\mathrm{M} / 2 \mathrm{y}$ & $\mathrm{F} / 11 \mathrm{~m}$ & $\mathrm{M} / 4 \mathrm{y}$ & F/6y & $\mathrm{F} / 7 \mathrm{y}$ & $\mathrm{F} / 7 \mathrm{y}$ & $\mathrm{M} / 20 \mathrm{~m}$ \\
\hline Albumin $(\mathrm{g} \%)$ & 1.63 & 1.20 & 1.80 & 1.20 & 1.70 & 2.20 & 2.00 \\
\hline Cholesterol (mg\%) & 227 & 645 & 390 & 650 & 350 & 343 & 388 \\
\hline Proteinuria (mg/Kg/day) & 130 & 78 & 97 & 150 & 265 & 80 & $2.02^{\mathrm{c}}$ \\
\hline Renal biopsy $^{\mathrm{d}}$ & $\mathrm{Nd}$ & MPGN & MCD & FSGS & MCD & FSGS & MCD \\
\hline Serological tests ${ }^{\mathrm{e}}$ & Negative & Negative & Negative & Negative & Negative & Negative & Negative \\
\hline Anti-Toxoplasma antibodies & $\mathrm{IgM} / \mathrm{IgG}+$ & $\operatorname{IgM} / \operatorname{IgG}+$ & IgM/IgG+ & $\operatorname{IgM} / \operatorname{IgG}+$ & $\mathrm{IgM} / \mathrm{IgG}+$ & $\operatorname{IgM} / \operatorname{IgG}+$ & $\operatorname{IgM+}$ \\
\hline Remission & Complete & Complete & Complete & Complete & Partial & Partial & Partial \\
\hline
\end{tabular}

a - M-male; F-female; b - m-months; y-years; c - protein/creatinine ratio; d - nd-not done; MPGN-mesangial proliferative glomerulonephritis; MCD-minimal histological injury; FSGS-focal segmental glomerulosclerosis; e - performed tests for CMV, rubella and syphilis.

The follow-up ranged from six months to nine years.

\section{RESULTS}

Case 1: Male, 2 years and 4 months old, born and raised in São Paulo (State of São Paulo). Presented diarrhea and vomiting without fever for two days; developed a cough and generalized edema. He kept those symptoms for 10 days, requiring hospitalization. On admission the patient showed regular general conditions, pallor $(++/ 4+)$, with lower extremity edema $(+/ 4+)$ without changes in other systems.

The patient remained hospitalized for 15 days, receiving during 14 days antibiotics and diuretics, and also starting specific treatment for toxoplasmosis, continued for one month. He evolved with normalization of proteinuria and serum albumin level, responding to the specific schema for toxoplasmosis. It was not necessary to introduce either steroids or other drugs routinely used in the treatment of nephrotic syndrome. Accompanied for six months the patient did not show any recurrence. Due to the favorable evolution the patient was not submitted to renal biopsy.

Case 2: Female, 11 months, born and raised in Barueri (State of São Paulo), presented with generalized edema, cough and wheeze, which was maintained for 15 days and she was then hospitalized. On admission the patient was in regular conditions; pale $(++/ 4+)$. Cardiovascular and respiratory apparatus without changes; abdomen with ascites; showed edema of the abdominal wall and lower limbs (+/4+).

The patient was submitted to treatment for toxoplasmosis with sulfadiazine and pyrimethamine for 20 days developing megaloblastic anemia; then, $10 \mathrm{mg}$ of folinic acid was intravenously administered during five days. After spiramycin ( $3 \mathrm{~g} /$ day) was introduced for 40 days. Two months after, still without remission, the patient was submitted to renal biopsy, revealing mesangial proliferative glomerulonephritis, with negative immunofluorescence. She received, then, pulse therapy with methylprednisolone $(30 \mathrm{mg} / \mathrm{kg} /$ day, maximum $1 \mathrm{~g}$ ), eight doses on alternate days, followed by prednisone $\left(35 \mathrm{mg} / \mathrm{m}^{2}\right)$ every other day. Sulfadiazine, pyrimethamine and folinic acid for one month were reintroduced, observing standards of proteinuria and serum albumin levels. Over the next six months the dosage of corticosteroids was gradually reduced and after seven years of follow-up the patient remains in complete remission.
Case 3: Male, 4 year-old, began to experience morning swelling of both eyelids, after the lower limbs were also affected. Laboratory tests confirmed a case of nephrotic syndrome.

The patient was treated with sulfadiazine, pyrimethamine and folinic acid for one month showing partial remission of symptoms. The same schema was continued for one month more in addition to prednisone $\left(60 \mathrm{mg} / \mathrm{m}^{2} /\right.$ day, for 28 days $)$ and the patient remained in remission during four months. In the next 12 months the patient showed six episodes of relapse, accompanied by respiratory symptoms. Then, renal biopsy was performed revealing minimal histological injury. Cyclophosphamide $(2.5 \mathrm{mg} / \mathrm{kg} /$ day for 60 days $)$ was introduced with evidence of complete remission.

Case 4: Female, 6 year-old, born and raised in Santos (State of São Paulo), revealed generalized edema, oliguria, cough and fever. Then, she was hospitalized with a diagnosis of nephrotic syndrome and pneumonia; although no data related to treatment administered during that hospitalization was obtained. The patient was discharged with prescription of prednisone $(1 \mathrm{mg} / \mathrm{kg}$ on alternate days). In the following months the patient had recurrence of edema and was referred to our clinic for follow-up. On admission the patient was in regular conditions, pale $(+/ 4+)$. Cardiac and respiratory auscultations were unchanged; abdomen with ascites and edema of the wall; liver was palpable $2 \mathrm{~cm}$ below the right costal margin; lower extremity edema $(++/ 4+)$; teeth in poor condition.

The treatment was started with sulfadiazine, pyrimethamine and folinic acid combined with prednisone $\left(35 \mathrm{mg} / \mathrm{m}^{2}\right.$ on alternate days $)$ for one month, bringing about edema regression, but maintaining proteinuria. The treatment for toxoplasmosis was maintained for another month, raising the dose of prednisone to $60 \mathrm{mg} / \mathrm{m}^{2}$ daily, resulting in total remission of the symptoms. In the following six months recurrence occurred and the patient underwent pulse therapy with methylprednisolone ( $30 \mathrm{mg} / \mathrm{kg} /$ day), eight doses on alternate days, with clinical improvement. The patient was submitted to a renal biopsy showing focal segmental glomerulosclerosis, with negative immunofluorescence. In the following months the dose of corticosteroids was gradually reduced until its suspension. The follow-up after nine years revealed that the patient remained in complete remission, although non-nephrotic proteinuria persisted, requiring treatment. 
TOPOROVSKI, J.; ROMANO, S.; HARTMANN, S.; BENINI, W. \& CHIEFFI, P.P. - Nephrotic syndrome associated with toxoplasmosis. Report of seven cases. Rev. Inst. Med. Trop. Sao Paulo, 54(2): 61-4, 2012.

Case 5: Male, 7 year-old, presenting generalized edema. The patient was treated with sulfadiazine, pyrimethamine and folinic acid for one month and prednisone $\left(60 \mathrm{mg} / \mathrm{m}^{2}\right)$ daily for four weeks with no response. Because of this, the patient underwent renal biopsy which showed minimal histological injury, with positive immunofluorescence for IgM and $\mathrm{C} 3$. Then, the patient received seven doses of methylprednisolone (30 mg/kg/day) on alternate days, combined with cyclosphosphamide (2.5 mg/kg/day, total 92 doses) maintaining nephrotic proteinuria $(290 \mathrm{mg} / \mathrm{kg} /$ day $)$. Later on it was introduced cyclosporine $(4 \mathrm{mg} / \mathrm{kg} /$ day for eight months) and the patient showed a clinical and laboratory improvement (proteinuria: $35 \mathrm{mg} / \mathrm{kg} /$ day; albumin: $2.7 \mathrm{~g} \%$ ). $\mathrm{He}$ then received mycophenolate mofetil $\left(500 \mathrm{mg} / \mathrm{m}^{2}\right.$, over $\left.15 \mathrm{months}\right)$ showing a partial remission. Due to the development of cataract and pancreatitis the administration of mycophenolate and pulse therapy with methylprednisolone was discontinued. Vincristine was, then, introduced (four week doses of $1 \mathrm{mg} / \mathrm{m}^{2}$, followed by four monthly doses of $1.5 \mathrm{mg} / \mathrm{m}^{2}$ ) and the patient evolved with clinical improvement. Then, the administration of levamisole $(2.5 \mathrm{mg} / \mathrm{kg} / \mathrm{day})$ started on alternate days, continuing the administration of prednisone. After two years the patient remained with nephrotic proteinuria of $75 \mathrm{mg} / \mathrm{kg} / \mathrm{day}$ and $2.7 \mathrm{~g} \%$ of serum albumin without clinical decompensation.

Case 6: Female, 7 year-old, had generalized edema with frothy urine one week in June 2009 and was referred to the clinic of pediatric nephrology. At the first visit the patient was in good general condition, with both eyelids edema $(+/ 4+)$, abdomen with ascites and edema of the lower limbs $(++/ 4+)$.

The treatment was started with prednisone $\left(60 \mathrm{mg} / \mathrm{m}^{2}\right.$, daily) for six weeks, combined with sulfadiazine, pyrimethamine and folinic acid, without any clinical and laboratory improvement. After, renal biopsy focal segmental glomerulosclerosis was found, with positive immunofluorescence for IgM and C3. Then, cyclosporine $(4 \mathrm{mg} / \mathrm{kg} /$ day) was introduced plus prednisone $\left(35 \mathrm{mg} / \mathrm{m}^{2}\right)$ in alternate days. After three months the patient progressed with partial remission (proteinuria: $120 \mathrm{mg}$ and serum albumin $3.4 \mathrm{~g} \%$ ). Administration of cyclosporine and prednisone was maintained and after the follow-up of 12 months the patient remained in partial remission, with normal albumin and non-nephrotic proteinuria.

Case 7: Male, one year and eight months old, was diagnosed with nephrotic syndrome with positive serology ( $\operatorname{IgM})$ for toxoplasmosis in another hospital, being treated with methylprednisolone pulse therapy (six doses), combined with anti-Toxoplasma therapy for one month. Due to the absence of clinical and laboratory improvement the patient was referred to our service.

The patient was again subjected to pulse therapy with methylprednisolone (six doses on alternate days) maintaining proteinuria and hypoalbuminemia. He was submitted to renal biopsy showing minimal histological lesions, with negative immunofluorescence. Cyclosporine $(4 \mathrm{mg} / \mathrm{kg} / \mathrm{day})$ plus prednisone $\left(35 \mathrm{mg} / \mathrm{m}^{2}\right)$ on alternate days was, then, introduced, resulting in partial remission (normalization of serum albumin level and non-nephrotic proteinuria) after six months.

The clinical and laboratorial data are summarized in the Table 1.

\section{DISCUSSION}

In patients with clinical diagnosis of nephrotic syndrome it is mandatory to proceed to the investigation of secondary causes of disease. There are reports of association of nephrotic syndrome and infection by Toxoplasma gondii in humans, although the cause-effect relationship has not been fully established.

In fact, reports of nephrotic syndrome associated with toxoplasmosis are very scarce and, generally, those are patients with the congenital form of toxoplasmosis ${ }^{2}$. However, the occurrence of nephrotic syndrome in an adult immunocompetent woman after infection with $T$. gondii has already been reported ${ }^{10}$.

Human infection by $T$. gondii has a worldwide distribution and generally high frequency. Recent seroepidemiological surveys performed in different segments of the Brazilian population revealed infection rates ranging from 32.4 to $74.5 \%$, depending on the age, with highest values occurring in adults ${ }^{3,16,17,18}$. In other countries high rates of human infection with $T$. gondii can also be found ${ }^{1,6,8,11,15}$.

The main renal diseases associated with parasitic infections are mesangioproliferative glomerulonephritis or tubular necrosis; minimalchange disease or focal segmental glomerulosclerosis are found more rarely ${ }^{19,20}$. The majority of reports about renal lesions associated with toxoplasmosis refer to acute renal failure due to the deposition of sulfadiazine crystals in the urinary tract after treatment with this $\operatorname{drug}^{20}$. However, the mechanisms of renal injury in the association of nephrotic syndrome and toxoplasmosis are not well understood. HULDT $(1971)^{5}$ experimentally demonstrated renal lesion with the deposition of immunoglobulin and immune complexes in glomeruli of mice infected with a low virulence $T$. gondii strain. Similar experiments in rabbits showed the same results. The histological picture found in human cases ranges from minimal histological injury to focal glomerulosclerosis ${ }^{14}$, a pattern similar to that observed in our patients.

The seven patients included in this report had an acute infection by T. gondii, serologically diagnosed, without clinical manifestations of the disease. Because of the simultaneous occurrence of nephrotic syndrome they were submitted to specific treatment for toxoplasmosis, the complete remission of the clinical and laboratory manifestations resulting in one of them (case 1) without using steroids or other immunosuppressant drugs. In the other patients it was necessary to introduce treatment for the nephrotic syndrome besides the anti-Toxoplasma therapy. In three patients a favorable response was observed and in the other three only a partial remission of the clinical manifestations occurred.

The data obtained from the observation of these seven patients support the need to investigate the possible occurrence of an acute infection by T. gondii in individuals who develop nephrotic syndrome without any previous history of kidney disease, especially when it comes to children.

\section{RESUMO}

\section{Síndrome nefrótica associada à toxoplasmose. Relato de sete casos.}

Ocorrência concomitante de síndrome nefrótica e infecção aguda por Toxoplasma gondii em seres humanos é situação pouco frequente. 
No presente trabalho são relatados sete casos de crianças, com idade variável entre 11 meses e sete anos, que apresentavam síndrome nefrótica e infecção aguda por T. gondii assintomática. Em um dos pacientes o tratamento específico anti-Toxoplasma foi suficiente para controlar clínica e laboratorialmente as manifestações da doença. Nos demais foi preciso administrar corticosteróides ou outras drogas imunossupressoras. Após introdução desse esquema três pacientes apresentaram remissão completa dos sintomas; os demais apenas remissão parcial.

\section{REFERENCES}

1. Al-Hindi A, Al-Helou T, Al-Helou Y. Seroprevalence of Toxoplasma gondii, cytomegalovirus, rubella virus and Chlamydia trachomatis among infertile women attending in vitro fertilization center, Gaza Strip, Palestine. J Egypt Soc Parasitol. 2010;40:451-8

2. Beale MG, Strayer DS, Kissane JM, Robson AM. Congenital glomerulosclerosis and nephrotic syndrome in two infants. Speculations and pathogenesis. Amer J Dis Child. 1979;133:842-4.

3. Francisco FM, Souza SLP, Gennari SM, Pinheiro SR, Muradian V, Soares RM. Seroprevalence of toxoplasmosis in a low-income community in the São Paulo municipality, SP, Brazil. Rev Inst Med Trop Sao Paulo. 2006;48:167-70.

4. Haskell L, Fusco MJ, Ares L, Sublay B. Disseminated toxoplasmosis presenting as symptomatic orchitis and nephrotic syndrome. Am J Med Sci. 1989;298:185-90.

5. Huldt G. Studies on experimental toxoplasmosis. Ann N Y Acad Sci.1971,177:146-55.

6. Jeannel D, Niel G, Costagliola D, Danis M, Traore BM, Gentillini M. Epidemiology of toxoplasmosis among pregnant women in the Paris area. Int J Epidemiol. 1988;17:595602 .

7. Lam C, Imundo L, Hirsch D, Yu Z, D’Agati V. Glomerulonephritis in a neonate with atypical congenital lupus and toxoplasmosis. Pediatr Nephrol.1999;13:850-3.

8. Makki SM, Abdel-Tawab AH. Anti-Toxoplasma gondii antibodies among volunteer blood donors in eastern Saudi Arabia. J Egypt Soc Parasitol. 2010;40:401-12.

9. Massière JP, Delafaye C, Le Guen E, Condat D. Acquired toxoplasmosis associated with nephrotic syndrome in an adult. Presse Med. 1989;18:1393.
10. Montoya JG, Kovacs JA, Remington JS. Toxoplasma gondii. In: Mandell GL, Bennett JE, Dolin R, editors. Principles and practice of infectious diseases. $6^{\text {th }}$ ed. Philadelphia: Elsevier; 2005. p. 3170-98.

11. Olusi T, Gross U, Ajayi J. High incidence of toxoplasmosis during pregnancy in Nigeria. Scand J Infect Dis. 1996;28:645-6.

12. Oseroff A. Toxoplasmosis associated with nephrotic syndrome in an adult. South Med J. 1988;81:95-6.

13. Roussel B, Pinon JM, Birembaut P, Rullier J, Pennaforte F. Syndrome néphrotique congénital associé à une toxoplasmose congénitale. Arch Fr Pediatr. 1987;44:795-7.

14. Shahin B, Papadopoulou ZL, Jenis EH. Congenital nephrotic syndrome associated with congenital toxoplasmosis. J Pediatr. 1974;85:366-70.

15. Sitoe SP, Rafael B, Meireles LR, Andrade HF Jr, Thompson R. Preliminary report of HIV and Toxoplasma gondii occurrence in pregnant women from Mozambique. Rev Inst Med Trop Sao Paulo. 2010;52:291-5.

16. Souza CO, Tashima NT, Silva MA, Tumitan AR. Estudo transversal de toxoplasmose em alunas de um curso superior da região de Presidente Prudente, Estado de São Paulo. Rev Soc Bras Med Trop. 2010;43:59-61.

17. Spalding SM, Amendoeira MRR, Klein CH, Ribeiro LC. Serological screening and toxoplasmosis exposure factors among pregnant women in South of Brazil. Rev Soc Bras Med Trop. 2005;38:173-7.

18. Sroka S, Bartelheimer N, Winter A, Heukelbach J, Ariza L, Ribeiro H, et al. Prevalence and risk factors of toxoplasmosis among pregnanat women in Fortaleza, Northeastern Brazil. Am J Trop Med Hyg. 2010;83:528-33.

19. Van Velthuysen MLF. Glomerulopathy associated with parasitic infections. Parasitol Today. 1996;12:102-7.

20. Van Velthuysen MLF, Florquin S. Glomerulopathy associated with parasitic infections. Clin Microbiol Rev. 2000;13:55-66.

21. Wickbom B, Winberg J. Coincidence of congenital toxoplasmosis and acute nephritis with nephrotic syndrome. Acta Paediatr Scand. 1972;61:470-2.

Received: 18 October 2011

Accepted: 23 February 2012 